\title{
Aplikasi Penerimaan dan Pengeluaran Kas Berbasis Web dan Whats App Gateway
}

\author{
Lutfi Hakim ${ }^{1, *}$, Sepyan Purnama Kristanto², Mohammad Nur Shodiq ${ }^{3}$, Eka Amaliyah ${ }^{4}$ \\ 1,2,3,4 Teknik Informatika, Politeknik Negeri Banyuwangi, Banyuwangi, Indonesia \\ Email: 1,*1utfi@poliwangi.ac.id, ${ }^{2}$ sepyan@poliwangi.ac.id, ${ }^{3}$ noer.shodiq@poliwangi.ac.id, \\ ekaamalia031@gmail.com \\ *) Email Penulis Utama
}

\begin{abstract}
Abstrak-SMK Nurut Taqwa Songgon merupakan salah satu sekolah berbasis pesantren yang berada di Banyuwangi. Sekolah ini terbilang relatif baru sehingga banyak sarana, prasarana dan sistem layanan sekolah yang masih perlu ditingkatkan lagi terutama di bidang teknologi informasi. Pada SMK ini, sistem penerimaan dan pengeluaran kas masih menggunakan cara konvensional yakni dengan menulis secara manual di buku. Hal ini menyebabkan proses yang dilakukan kurang optimal dan banyak sekali kendala yang dihadapi seperti proses pengurusannya yang cukup lama, rentan kesalahan dan kehilangan data. Berdasarkan permasalahan yang ada, pada penelitian ini dilakukan pengembangan aplikasi berbasiskan web dan WhatsApp Gateway yang dapat membantu pekerjaan bendahara dalam pengelolaan kas sekolah. Metode pengembangan sistem yang digunakan dalam aplikasi ini menggunakan metode RAD (Rapid Application Development). Aplikasi ini juga dibangun dengan menggunakan bahasa pemrograman PHP dengan framework Codelgniter. Hasil dari penelitian ini didapatkan bahwa aplikasi ini dapat mempermudah bendahara dalam mengelola data tanggungan siswa dan pencatatan transaksi pengeluaran sekolah, seperti penggajian karyawan, pengelolaan pembayaran siswa dan melihat transaksi penerimaan dan pengeluaran secara keseluruhan di SMK Nurut tanpa memerlukan waktu yang panjang lagi, sedangkan untuk para wali murid dapat terbantu dalam memantau pembayaran yang dilakukan oleh anaknya melalui fitur Whatsapp Gateway. Berdasarkan pengujian yang dilakukan dengan menggunakan metode black box testing didapatkan bahwa semua fitur yang dikembangkan dapat berjalan dengan baik, sedangkan pengujian dengan pengisian kuisioner berdasarkan 4 aspek menurut ISO 9126 yakni aspek fungsionalitas, informasi, kebergunaan dan efisiensi didapatkan tingkat kualitas sistem berkriteria baik dengan presentase sebesar $88.5 \%$.
\end{abstract}

Kata Kunci: sistem informasi berbasis web, pengelolaan data kas sekolah, framework CodeIgniter, blackbox testing, rapid application development

\begin{abstract}
Vocational High School of Nurut Taqwa Songgon is a boarding school based in Banyuwangi. This school is relatively new, so there are many school facilities, infrastructures and service systems that still need to be improved, especially in the field of information technology. The system of cash receipt and payment of the school is still uses conventional method by writing manually in books. This causes that the process to be carried out is not optimal and there are many obstacles encountered such as the long processing process, human error and data loss. Based on the existing problems, this research carried out the development of a web-based application and WhatsApp Gateway can help the treasurer work in managing school finances. The system development method used in this application uses Rapid Application Development (RAD) and is built by using the CodeIgniter Framework. The results of this study found that this application can make it easier for treasurer to manage student dependency data and record school expenditure transactions, such as employee payroll, student payment management and see the overall receipt and expenditure transactions at Vocational High School of Nurut Taqwa Songgon without requiring much longer, while for student guardians can be helped in monitoring payments made by their children through the WhatsApp Gateway feature. Based on the tests carried out using black box testing method, it was found that all the features developed were able to run weel, while testing by filling out a questionnaire based on four aspects according to ISO 926, name aspects of functionality, information, usability and efieciency, obtained a good quality system level with a percentage of $88.5 \%$.
\end{abstract}

Keywords: web-based applications, managemenet of school cash data, framework codeIgniter, blackbox testing, rapid application development.

\section{PENDAHULUAN}

Perkembangan teknologi informasi yang semakin pesat mendorong implementasi di berbagai sektor seperti di instansi pemerintahan, perkantoran, perbankan dan pendidikan. Data Badan Pusat Statistik (BPS) menunjukkan bahwa penggunaan Teknologi Informasi dan Komunikasi (TIK) mengalami pertumbuhan sebesar 2,23\% dari tahun 2017 hingga 2018 [1]. Peningkatan ini mendorong implementasi TIK dalam berbagai sektor menjadi suatu keharusan dan kebutuhan. Karena dengan adanya implementasi ini dapat meningkatkan efisiensi pelayanan, manajemen data, sehingga dapat meminimalisir kerusakan atau kehilangan data dan memotong proses bisnis yang panjang.

SMK Nurut Taqwa Songgon adalah salah satu sekolah kejuruan di Banyuwangi yang berkonsep unit sekolah berasrama. Sekolah kejuruan ini merupakan salah satu sekolah swasta yang berbasiskan pesantren yang masih memerlukan banyak sentuhan di bidang teknologi informasi dalam berbagai pelayanan. Berdasarkan survey lapangan yang dilakukan ditemukan bahwa sistem pengelolaan data penerimaan dan pengeluaran kas masih 
dilakukan secara konvensional, seperti pengolahan data transaksi masih dicatat disebuah buku dan di Microsoft Excel seperti yang ditunjukkan pada gambar 1. Oleh karena itu, sistem yang digunakan sekarang masih banyak memiliki keterbatasan sehingga rentan sekali terhadap kehilangan data. Selain itu juga, dalam proses pencatatan transaksi dan pembuatan laporan masih manual, sehingga membutuhkan waktu yang cukup lama dan kurang akurat karena harus menghitung terlebih dahulu besar jumlah setiap transaksi dengan satu per satu di dalam buku kas transaksi sekolah.

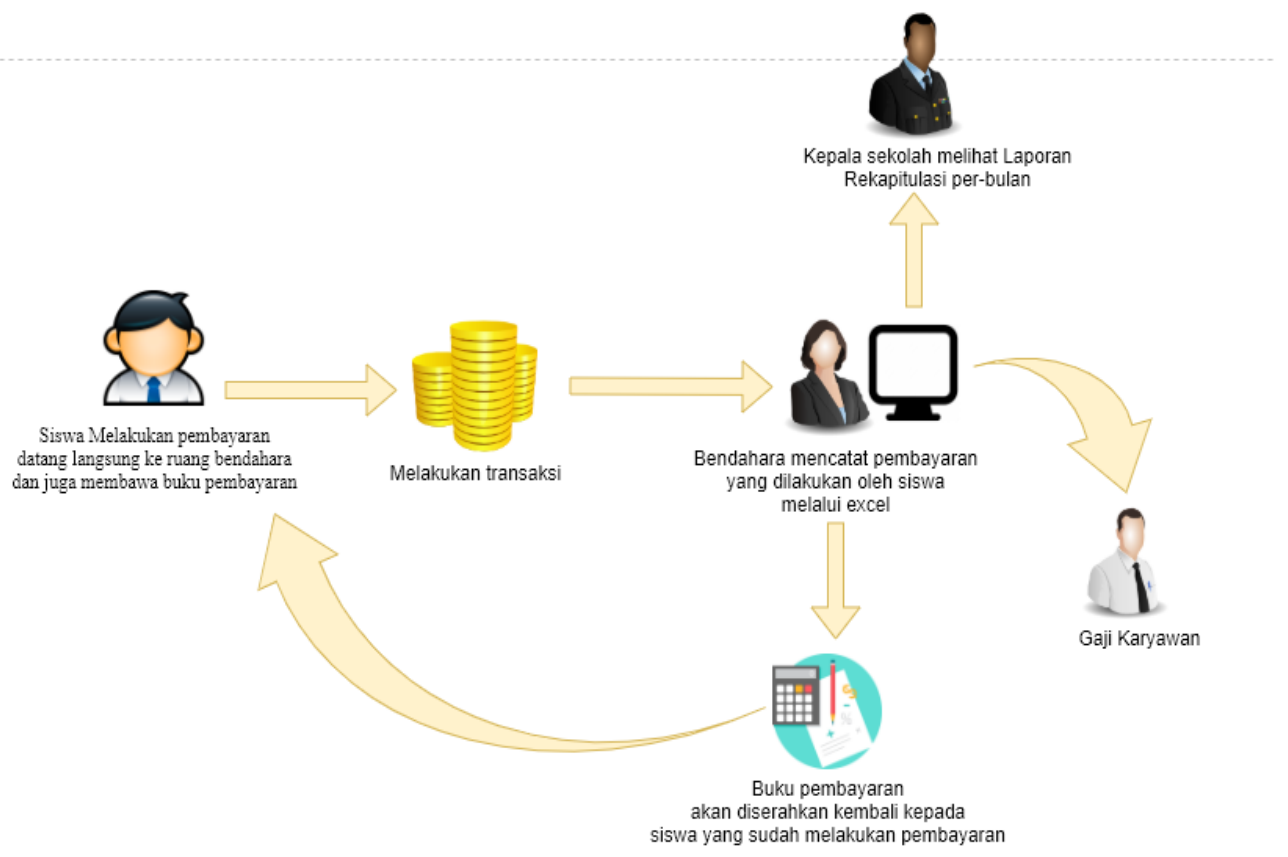

Gambar 1. Gambaran Sistem yang berjalan saat ini

Beberapa peneliti terdahulu telah melakukan pengembangan aplikasi untuk untuk mengatasi hal serupa. Arizona dkk mengembangkan aplikasi pengolahan data penerimaan dan pengeluaran kas di SMK Cahaya Bangsa. Aplikasi ini dapat menyimpan data siswa-siswa, data pegawai, transaksi pembayaran SPP, laporan penerimaan dan pengeluaran dan laporan rekapitulasi [2]. Abdul Rohman dkk. mengembangkan aplikasi sistem informasi administrasi pembayaran SPP siswa berbasis web di SMK AL-Amanah. Aplikasi ini dapat membuat list, manajemen dan grafik pembayaran [3]. M. Fitridiansyah dkk. membuat sistem informasi administrasi keuangan di SMKN 3 Sampit dengan fitur sistem pencatatan, transaksi dan pelaporan [4]. Damayanti dkk. Mengembangkan sistem informasi akuntansi untuk penerimaan dan pengeluaran kas pada KPRI Andan Jejama Kabupaten Pesawaran [5]. Fitur yang dikembangkan pada penelitian tersebut meliputi pencatatan data karyawan, anggotra, data kas masuk dan keluar, serta laporan jurnal penerimaan dan pengeluaran. Penelitian lain mengembangkan sistem informasi akuntansi penerimaan dan pengeluaran kas berbasis web dengan studi kasus di PT. Sinar Kapuas Cemerlang [6]. Pada aplikasi tersebut terdapat dua user yakni user bendahara sekaligus sebagai admin dan user Direktur. Berdasarkan beberapa penelitian yang telah dijabarkan di atas, aplikasi yang dikembangkan seluruhnya berupa aplikasi pencatatan tanpa menggunakan teknologi bantuan seperti SMS ataupun WhatsApp Gateway. WhatsApp Gateway atau juga dikenal dengan wablas merupakan fitur layanan whatsapp dan SMS API Gateway untuk pengiriman dan penerimaan pesan, notifikasi, pengaturan jadwal, tanda pengingat, dan pelacakan yang dikembangkan dengan tujuan membantu pengguna dalam mengembangkan bisnis dengan integrasi yang sederhana [7]. Penggunaan teknologi ini sangat membantu dalam mendukung proses konfirmasi dari transaksi yang telah dilakukan.

Berdasarkan permasalahan yang dipaparkan di atas, masalah sering terjadi kaitannya dengan pembayaran yang dilakukan oleh orang tua wali. Seringkali orang tua wali mengalami lupa dalam melakukan transaksi pembayaran yang dilakukan oleh anaknya. Sehingga orang tua seringkali abai terhadap tanggungan pembayaran dan yang paling parah adalah ketika sang anak tidak membayarkan uang yang diberikan oleh orang tua kepada pihak pesantren sehingga seharusnya sudah membayar tapi belum terbayarkan. Oleh karena itu perlu dikembangkan sebuah aplikasi yang dapat mengakomodir permasalahan yang terjadi dimana aplikasi tersebut dapat digunakan untuk mengelola penerimaan dan pengeluaran kas berbasis web serta menggunakan teknologi WhatsApp Gateway untuk mengirimkan konfirmasi pembayaran yang telah dilakukan oleh siswa kepada orang tua atau wali murid di SMK Nurut Taqwa Songgo Banyuwangi. Pemilihan teknologi WhatsApp Gateway untuk media pengiriman konfirmasi ke wali murid karena hampir sebagian besar orang tua murid menggunakan whatsapp dalam komunikasi. Selain itu, aplikasi ini lebih efektif digunakan dibandingkan dengan menggunakan 
SMS gateway [8]. Harapannya dengan aplikasi ini dapat membantu tugas bendahara sekolah dalam mengelola data siswa, data karyawan atau guru, mencetak bukti pembayaran dan slip gaji karyawan atau guru, serta memberikan informasi kepada orang tua siswa berkaitan dengan pembayaran yang telah dilakukan melalui WhatsApp Gateway.

\section{METODE PENELITIAN}

Metode yang digunakan dalam penelitian ini menggunakan Rapid Application Development (RAD). Metode RAD menggunakan metode berulang dalam mengembangkan sistem serta menekankan pada siklus pembangunan pendek, singkat, dan cepat. Jadi metode ini sesuai untuk menghasilkan sistem perangkat lunak dengan kebutuhan yang mendesak dan waktu yang relatif singkat dalam penyelesaiannya. RAD juga mempunyai kemampuan untuk menggunakan kembali komponen yang ada (reusable object) sehingga pengembang tidak perlu membuat dari awal lagi [9]. Secara umum, model ini memiliki lima tahap yang berbeda seperti yang ditunjukkan pada gambar berikut.

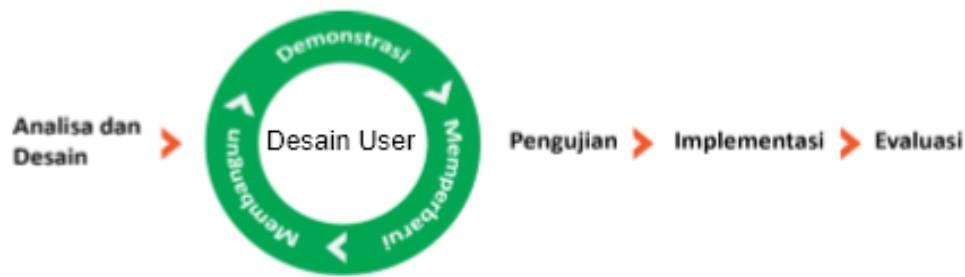

Gambar 2. Siklus Metode RAD

\subsection{Analisa dan Desain}

Tahap ini merupakan tahap awal dari penelitian ini. Pada tahap ini terbagi menjadi dua yaitu tahap analisa kebutuhan dan desain sistem.

a. Analisa Kebutuhan

Pada tahap analisa kebutuhan merupakan tahap identifikasi masalah dari sistem yang akan dikembangkan. Pada tahap ini mencakup proses survey lapangan dan studi literatur. Tahap survey lapangan meliputi proses analisis sistem yang telah berlangsung di sekolah pada saat ini dan menggali informasi berkaitan dengan rencana dari pihak sekolah dalam jangka pendek dan panjang, terutama berkaitan dengan penggunaan teknologi informasi di dalam pelayanan sekolah. Tahap ini dilakukan melalui survey atau pengamatan langsung dan juga melalui proses wawancara, terutama pegawai bagian bendahara. Berdasarkan tahap wawancara yang dilakukan didapatkan bahwa sistem pengolahan data penerimaan dan pengeluaran kas di SMK Nurut Taqwa Songgon masih dilakukan secara manual yakni mulai dari pengolahan data transaksi penerimaan dan pengeluaran yang masih dicatat disebuah buku dan di Microsoft excel untuk semua transaksi yang ada di sekolah. Hal ini mengakibatkan kurangnya efisiensi dalam pembuatan laporan dan rentan terjadi kehilangan. Selain tahap survey lapangan, pada tahap analisa kebutuhan juga melakukan studi literatur berkaitan dengan masalah yang akan ditangan. Studi literatur ini mencakup berbagai sumber mulai dari referensi dari jurnal ilmiah, buku bacaan dan buku tugas akhir.

\section{b. Desain Sistem}

Tahap ini merupakan tahap implementasi dari pemikiran dan perancangan sistem terhadap solusi dari permasalahan yang ada dengan menggunakan perangkat pemodelan sistem. Pada tahap ini dilakukan perancangan use case diagram, diagram hubungan entitas atau Entity Relationship Diagram (ERD), activity diagram dan desain mockup.

\subsection{Desain User (Pengguna)}

a. Membangun Sistem

Tahap ini merupakan tahap penulisan syntax atau kode program. Penulisan kode program merupakan penerjemahan desain yang telah dirancang ke dalam bahasa pemrograman yang bisa dikenali oleh komputer. Pengembangan aplikasi pada penelitian ini menggunakan framework CodeIgniter. Framework atau kerangka kerja CodeIgniter adalah sebuah web application network yang menggunakan prinsip model MVC (Model, View, Controller) dan bersifat opensource yang digunakan untuk membangun aplikasi berbasis web secara dinamis [10]. Framework CodeIgniter merupakan salah satu framework dari bahasa pemrograman PHP. PHP dipilih karena merupakan bahasa pemrograman yang dapat diterapkan pada berbagai sistem operasi dan mudah dipahami. Selain PHP, penulisan kode program juga menggunakan HTML, CSS dan framework bootstrap. Sedangkan basisdata yang digunakan adalah basis data MySQL, karena cocok digunakan dalam kasus dengan data yang mempunyai hubungan antar tabel dan memiliki kecepatan dalam menangani query sederhana. 


\section{b. Demonstrasi Sistem}

Tahap demonstrasi sistem adalah proses untuk memperlihatkan hasil sementara dari sistem yang telah dibangun. Hasil dari tahap ini berupa evaluasi kecil yang kemudian dilakukan perbaikan pada sistem yang mengalami kesalahan atau tidak sesuai dengan rancangan aplikasi. Proses demonstrasi sistem ini bersifat hanya menguji coba sementara dari proses coding yang telah dilakukan. Jika terdapat fitur atau coding yang belum sesuai maka akan dilanjutkan ke tahap selanjutnya yakni perbaharui sistem.

c. Perbaharui Sistem

Tahap ini merupakan tahap pembaharuan sistem apabila pada tahap demonstrasi sistem terdapat evaluasi yang membutuhkan perbaharuan. Tujuan utama perbaruan sistem adalah untuk memperbaiki sistem yang masih ada kekurangan sesuai dengan evaluasi yang dilakukan. Proses dari tahap membangun, demonstrasi dan perbaharui sistem dilakukan berulang sampai dengan aplikasi memenuhi target yang ditentukan di awal atau tahap perencanaan.

\subsection{Pengujian}

Pada tahap ini dilakukan pengujian aplikasi untuk melihat kesalahan, kekurangan dan tingkat kelayakan pada aplikasi yang telah dibuat. Tahap pengujian merupakan tahap dimana aplikasi yang dikembangkan hampir mendekati selesai. Pengujian sistem ini dilakukan untuk melihat bahwa sejauh mana kualitas aplikasi yang dikembangkan berdasarkan tata aturan pengembangan aplikasi. Pada penelitian ini, tahap pengujian sistem dilakukan dengan menggunakan Black-Box Testing dan pengisian kuisioner. Black-box testing merupakan teknik pengujian yang didasarkan pada detail aplikasi seperti dari sisi tampilan, fungsi-fungsi yang ada pada aplikasi, dan kesesuaian alur fungsi dengan bisnis proses yang diinginkan oleh pengguna. Pada pengujian ini lebih menguji tampilan luar atau interface dari suatu aplikasi agar mudah digunakan dan tidak melihat dan menguji source code program [11], [12]. Sedangkan pengujian melalui metode pengisian kuisioner untuk menguji empat aspek menurut ISO 9126 diantaranya aspek fungsionalitas, kualitas informasi, kebergunaan, efisien dari aplikasi yang dikembangkan [13], [14]. Hal ini dilakukan agar pada saat penerapan, sistem dapat dipastikan sistem dapat berjalan dengan baik dan tidak ada gangguan yang dapat mempengaruhi kinerja sistem yang dibuat. Proses pengujian ini dilakukan pada calon pengguna dari aplikasi yang dikembangkan yakni Kepala Sekolah, bendahara dan guru-guru di SMK Nurut Taqwa Songgon.

\subsection{Implementasi}

Implementasi sistem merupakan tahap penerapan sistem di SMK Nurut Taqwa Songgon kepada pengguna yang terkait atau end user. Tahap ini dilakukan agar aplikasi yang dikembangkan dapat dipastikan berjalan dengan baik dan sistem tidak memiliki gangguan. Setelah aplikasi sudah berjalan, selanjutnya diperlukan untuk proses pemeliharaan dan perkembangan pada aplikasi.

\subsection{Evaluasi}

Setelah tahap implementasi, proses selanjutnya adalah evaluasi dari penerapan aplikasi. Tahap ini menitikberatkan pada proses penghimpunan kekurangan dan ketidaksesuaian sistem serta cara penaggulangannya.

\section{HASIL DAN PEMBAHASAN}

\subsection{Desain Sistem}

Aplikasi penerimaan dan pengeluaran kas dibuat dengan tujuan untuk memberikan pelayanan prima, serta meningkatkan kualitas dan administrasi keuangan sekolah. Gambaran sistem dari aplikasi yang dikembangkan dapat dilihat seperti gambar 3, dimana jika siswa akan melakukan transaksi pembayaran untuk menyelesaikan tanggungannya, siswa harus datang ke kantor untuk menemui bendahara sekolah. Selanjutnya, siswa memilih tanggungan yang ingin dibayar. Administrasi keuangan sekolah memberikan atau mencetak print hasil pembayaran tanggungan siswa dan berikutnya wali murid akan otomatis menerima pesan WhatsApp apabila putra/putrinya telah melakukan pembayaran. Berikutnya, bendahara juga dapat melakukan pencatatan pembayaran gaji para karyawan/guru melalui aplikasi ini, dan kepala sekolah juga dapat memonitoring kegiatan keluar masuknya transaksi keuangan yang terjadi disekolah.

Layanan utama dari aplikasi ini adalah proses pengelolaan data keuangan, pengelolaan data pembayaran, data siswa, karyawan, data gaji karyawan, pengelolaan laporan keuangan dan grafik kas masuk dan keluar secara periodik. Pada aplikasi ini, bendahara akan masuk dan mengoperasikan aplikasi sesuai dengan hak akses yang dimiliki. Terdapat 2 (dua) pengguna utama yang memiliki hak akses yang berbeda seperti yang ditunjukkan pada gambar 4. 


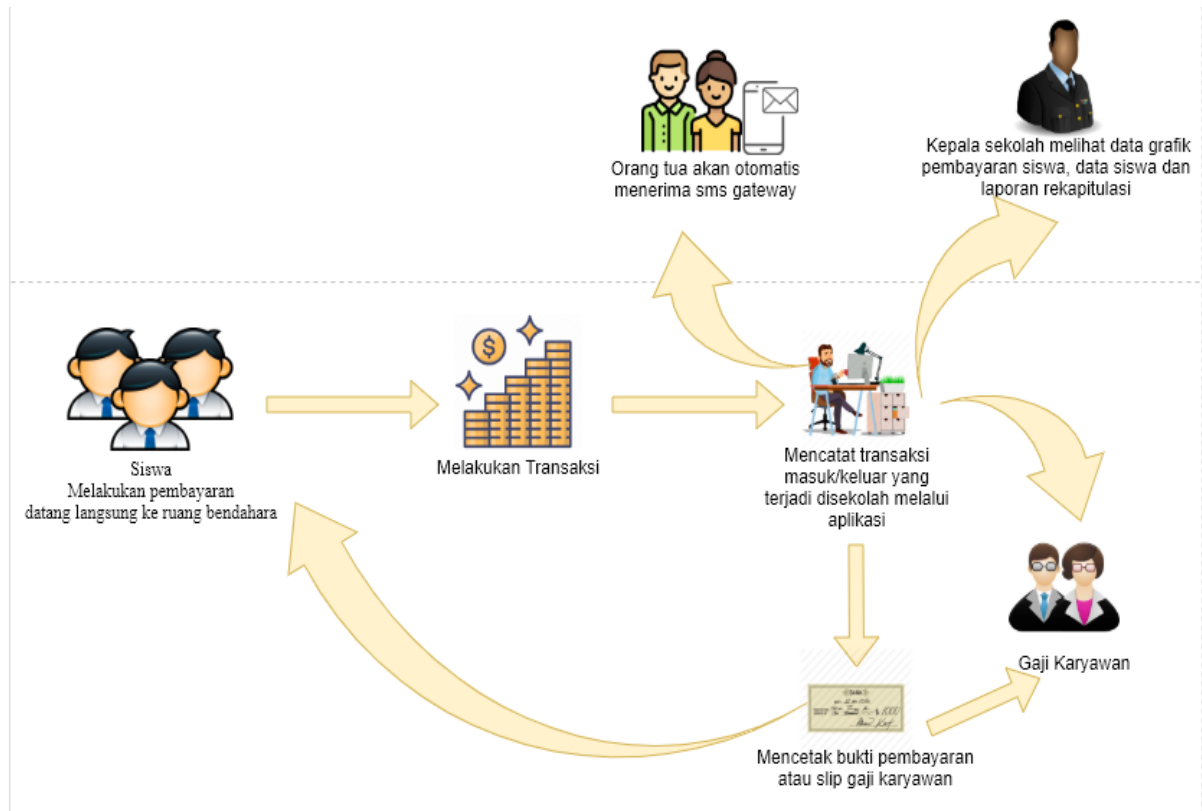

Gambar 3. Gambaran sistem yang diusulkan

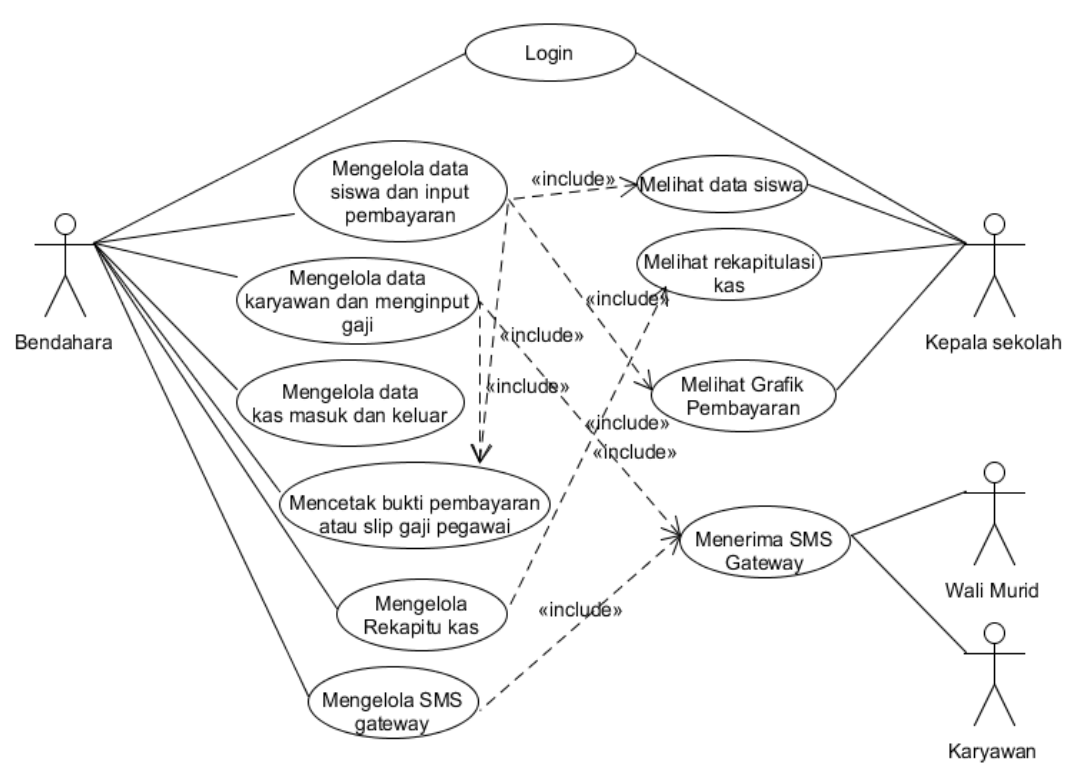

Gambar 4. Use Case Diagram

User Bendahara merupakan pengguna utama pada aplikasi ini dan sekaligus sebagai admin dari aplikasi ini. Bendahara memiliki hak akses untuk mengolah data pembayaran; mengelola data siswa, data karyawan, data pengeluaran; membuat laporan pemasukan dan pengeluaran kas; serta juga mengirimkan whatsapp gateway kepada wali murid yang putra atau putri telah melakukan pembayaran dan karyawan yang telah menerima gaji. Sedangkan user Kepala sekolah hanya bisa melihat data dan mencetak laporan rekapitulasi jika diperlukan. Seluruh transaksi yang dilakukan pada aplikasi ini disimpan dalam sebuah basis data. Pada aplikasi ini, terdapat 12 tabel basis data yang mempunyai relasi satu sama lain. Relasi tabel database tersebut digambarkan dalam Entity Relationship Diagram (ERD) pada gambar 5. 


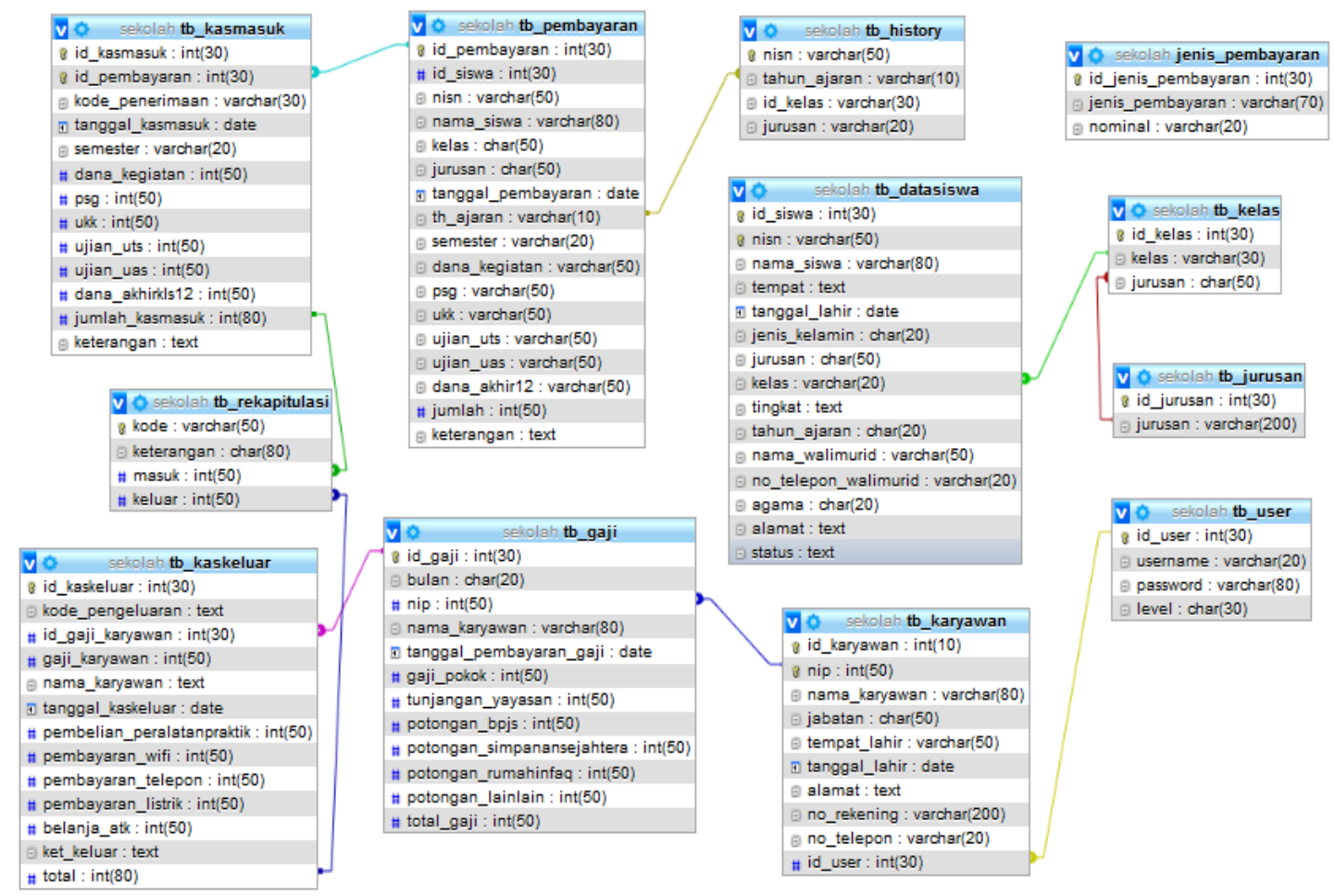

Gambar 5. Entity Relationship Diagram

\subsection{Tampilan Aplikasi}

Aplikasi penerimaan dan pengeluaran kas berbasis web dan WhatsApp Gateway ini mempunyai dua pengguna utama yakni bendahara dan kepala sekolah. Aplikasi ini juga memiliki beberapa tampilan, seperti yang dijelaskan pada bagian berikut:

a. Tampilan Login

Pada tampilan halaman login merupakan tampilan awal ketika aplikasi pertama kali dibuka oleh Bendahara atau Kepala sekolah untuk masuk pada aplikasi dengan memasukkan username dan password. Halaman login ditunjukkan pada gambar berikut.
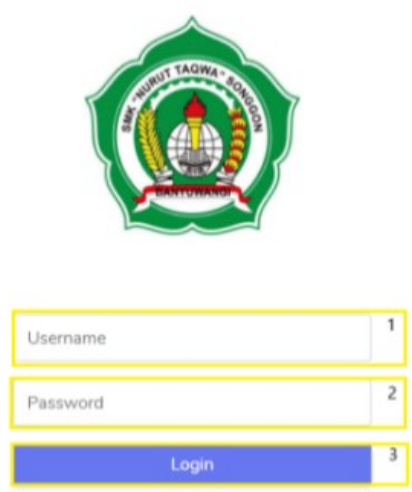

Gambar 6. Tampilan Login

b. Halaman Utama Bendahara

Halaman utama merupakan halaman yang dapat di akses oleh bendahara dan juga terdapat tampilan grafik kas masuk dan keluar yang bisa difilter berdasarkan bulan ataupun tahun sesuai kebutuhan. Selain itu juga terdapat jumlah dari siswa dan karyawan yang ada di sekolah. Pada halaman ini, bendahara dapat mengelola data siswa, data karyawan, data gaji, data pembayaran, kas masuk, kas keluar dan juga rekapitulasi. Gambar berikut merupakan tampilan dari halaman utama bendahara. 


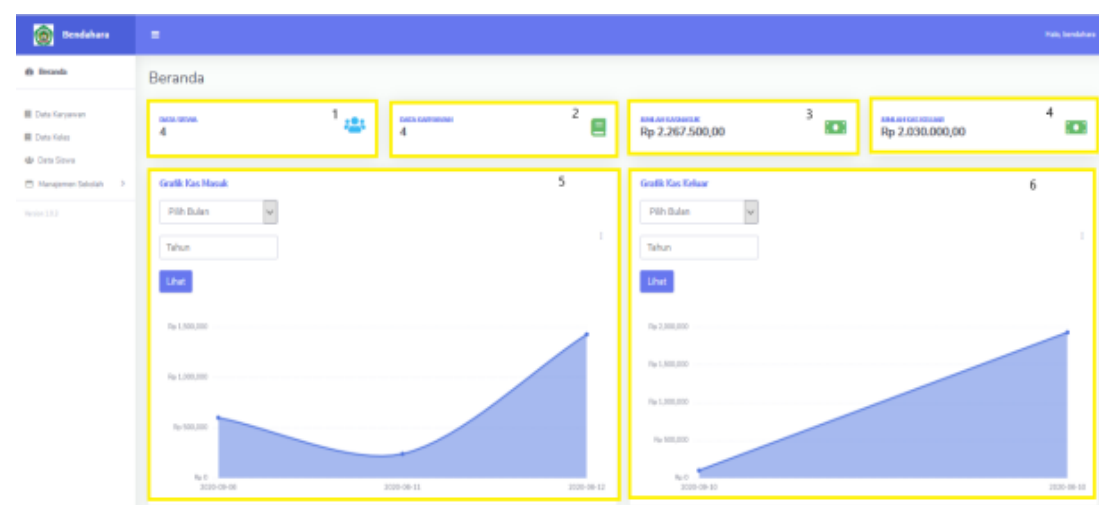

Gambar 7. Halaman Utama Bendahara

c. Menu Data Karyawan

Menu data karyawan merupakan fitur yang menampung data karyawan sekolah. Pada fitur ini juga dilengkapi fitur untuk menambahkan data karyawan baru. Bendahara menambahkan data NIP, nama karyawan, jabatan, nomer telpon, no. rekening, tempat lahir, tanggal lahir, dan juga alamat. Selain fitur menambahkan data, pada menu ini juga disediakan fitur untuk edit dan hapus data. Berikut adalah tampilan menu data karyawan ditunjukkan pada gambar berikut.

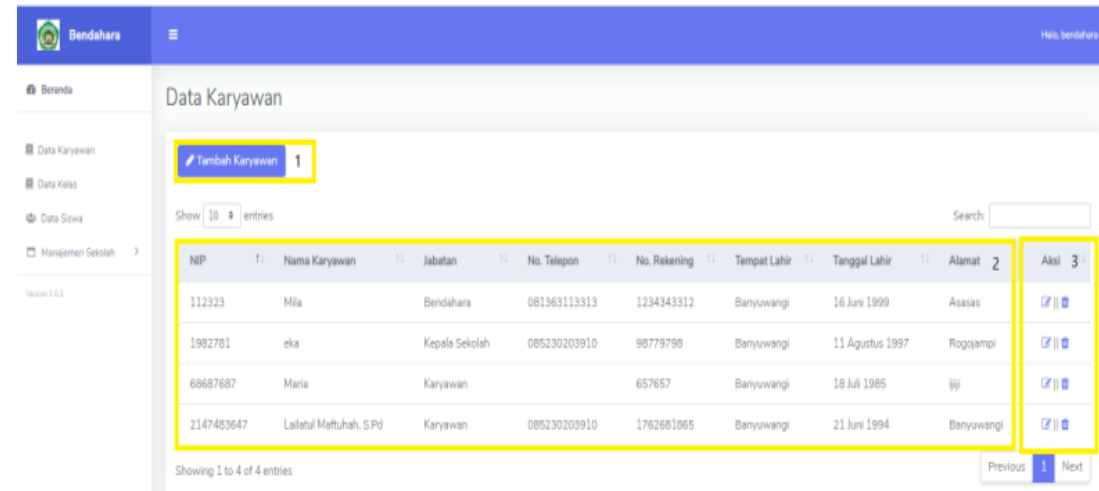

Gambar 8. Menu Data Karyawan

d. Menu Data Siswa

Menu data siswa merupakan fitur untuk mengelola data siswa. Bendahara dapat menambahkan dan memperbarui data NIS, nama siswa, tempat lahir, tanggal lahir, jenis kelamin, kelas, wali murid, nomor telepon, dan alamat. Sama seperti menu data karyawan, pada fitur ini juga disediakan tombol edit dan hapus data. Selain itu, pengguna juga dapat menyaring data berdasarkan fitur filter data yang telah disiapkan dan untuk tampilan dari menu ini ditunjukkan pada gambar berikut.

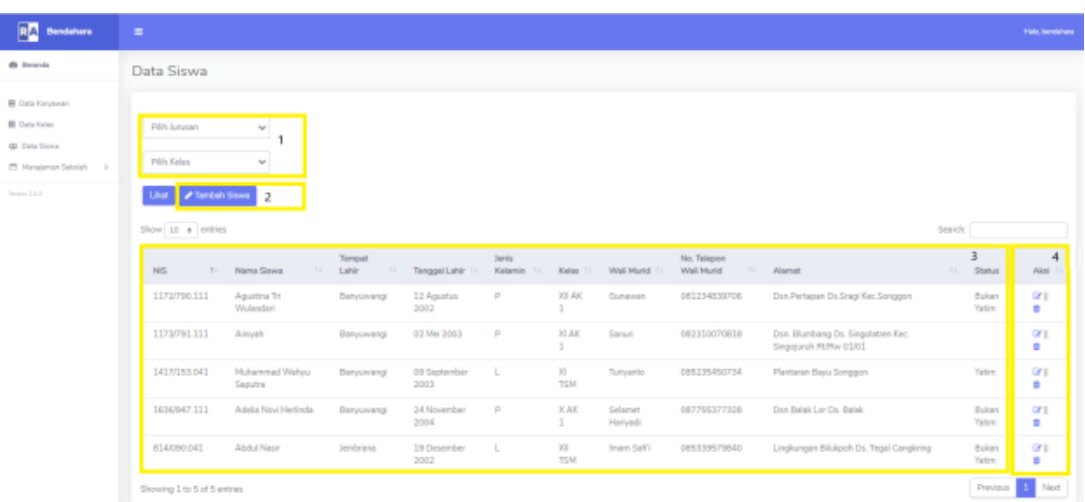

Gambar 9. Menu Data Siswa 
e. Menu Pembayaran

Menu pembayaran merupakan fitur untuk mengelola pembayaran yang dilakukan oleh siswa. Pada menu ini, pengguna dapat melihat seluruh transaksi pembayaran siswa serta menambahkan data pembayaran. Pada menu ini ada banyak pembayaran yang disediakan, seperti pembayaran dana kegiatan, PSG atau praktek kerja industri (prakerin), UKK (Ujian Kompetensi Akhir), UTS (Ujian Tengah Semester), UAS (Ujian Akhir Semester). Tampilan dari fitur pembayaran yang dapat dilihat pada gambar 10 .

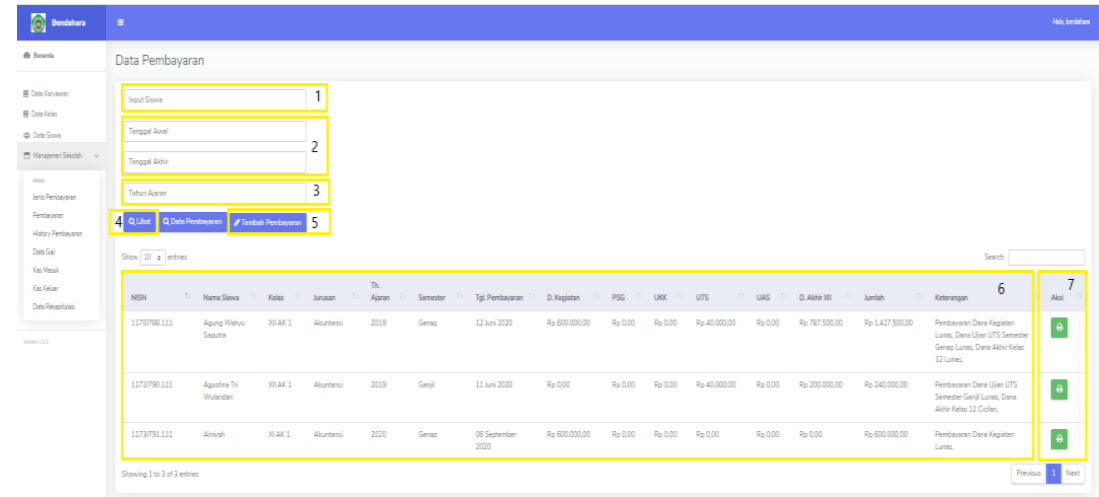

Gambar 10. Menu Pembayaran

Jika siswa atau siswi melakukan pembayaran dan bendahara telah melakukan penginputan data pembayaran maka bendahara dapat mencetakkan bukti pembayaran. Cetak bukti pembayaran ini dilakukan pada setiap siswa pada saat melakukan pembayaran pada hari itu juga untuk dijadikan bukti pembayaran (nota). Tampilan bukti pembayaran ditunjukkan pada gambar 11 .

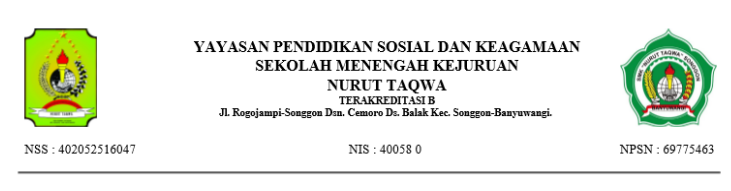

NOTA PEMBAYARAN TANGGAL 11 September 2020

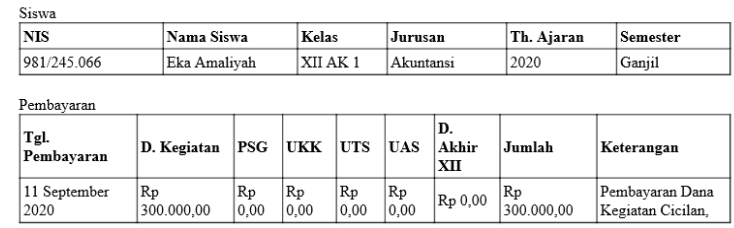

Gambar 11. Bukti Pembayaran

f. Menu Histori Pembayaran

Menu ini adalah fitur untuk melihat status pembayaran yang telah dilakukan para siswa apakah sudah lunas atau belum. Setelah siswa melakukan pembayaran, maka bendahara dapat melihat status pembayaran siswa yakni apakah sudah lunas atau belum. Untuk melihatnya, bendahara dapat menggunakan fitur pencarian berdasarkan nama siswa dan semester yang sedang berjalan. Kemudian, bendahara dapat meng-klik tombol lihat sehingga muncul status pembayaran siswa tersebut. Jika telah melihat history pembayaran, bendahara dapat mencetak status tanggungan siswa pada saat pengambilan raport atau dibutuhkan oleh wali murid. Tampilan dari fitur ini dapat ditunjukkan pada gambar berikut. 


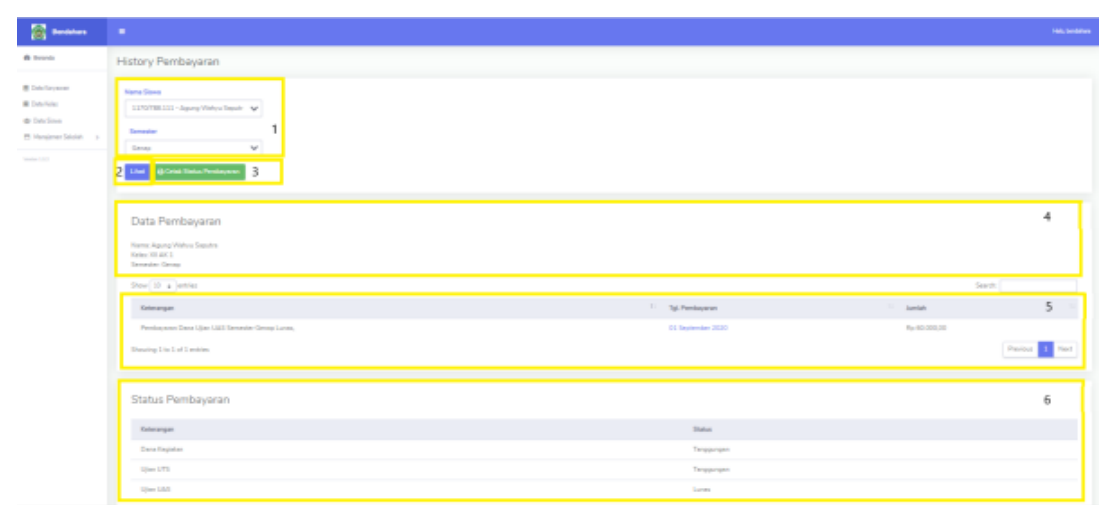

Gambar 12. Menu Histori Pembayaran

g. Menu Data Gaji

Menu data gaji adalah fitur untuk mencatat gaji para karyawan per bulannya. Pendapatan bersih karyawan akan dihitung berdasarkan gaji pokok dan tunjangan yayasan (jika ada) serta dikurangi dengan potongan-potongan (jika ada). Bendahara akan menambah gaji setiap karyawan lalu menghitung jumlahnya menyimpannya di database. Pada saat pendapatan bersih telah dikirimkan ke nomor rekening karyawan maka karyawan akan menerima pesan whatsapp gateway sesuai nomor whatsapp karyawan masing-masing. Fitur ini ditunjukkan pada tampilan gambar berikut.

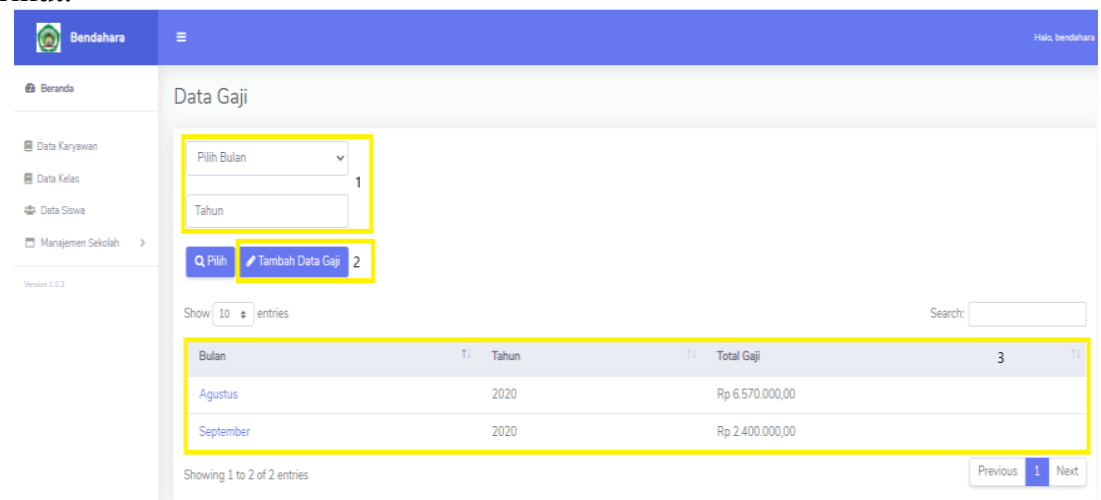

Gambar 13. Menu Data Gaji

h. Menu Kas Masuk

Menu ini merupakan fitur yang menghimpun data dari siswa yang telah melakukan pembayaran ditotal menjadi satu untuk perharinya. Fitur dari menu ini ditunjukkan pada gambar berikut.

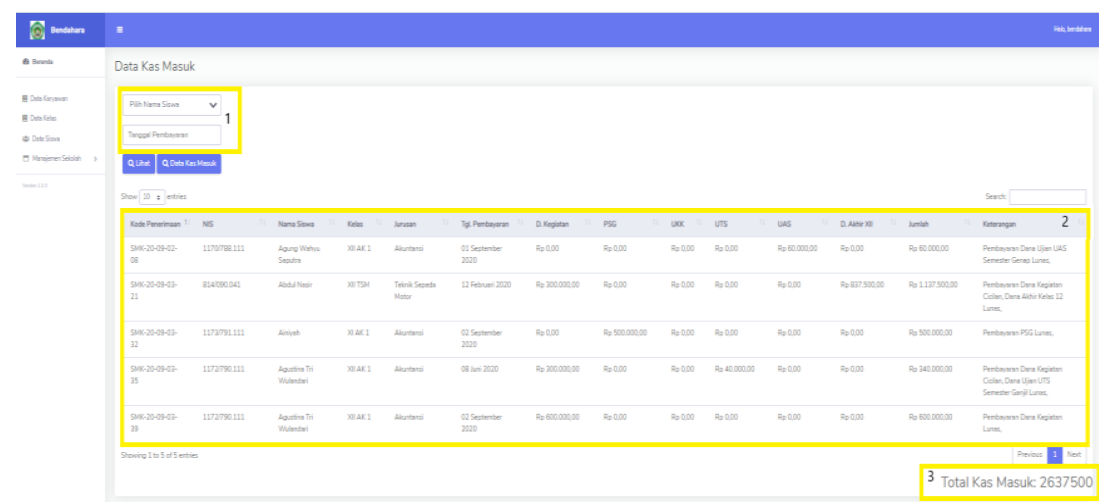

Gambar 14. Menu Kas Masuk

i. Menu Kas Keluar

Menu ini adalah fitur untuk mencatat transaksi yang keluar dari bendahara SMK seperti gaji karyawan, pembayaran wifi, pembayaran telepon, pembayaran listrik, belanja alat tulis kantor dan keperluan lainnya. Fitur dari menu ini ditunjukan pada gambar berikut. 


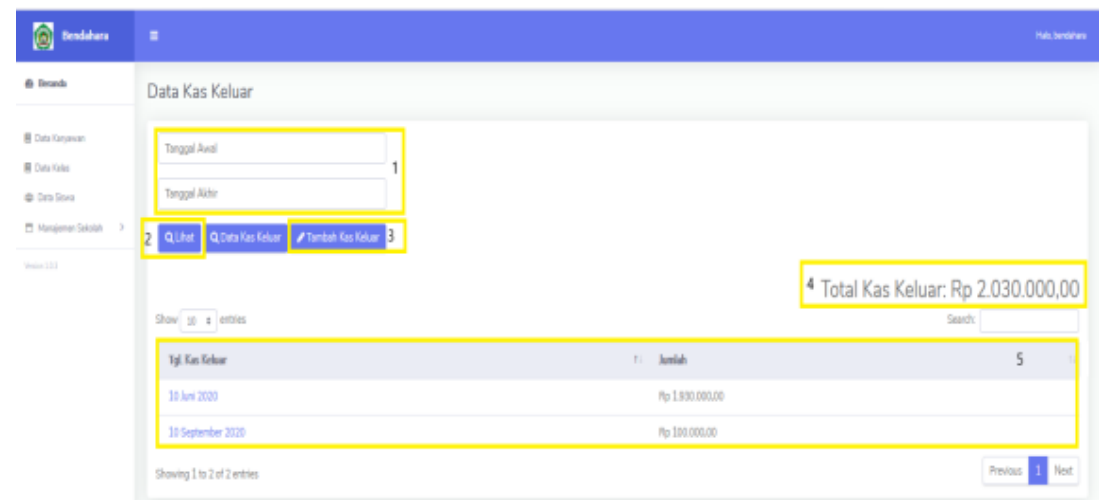

Gambar 15. Menu Kas Keluar

j. Menu Data Rekapitulasi

Menu ini adalah fitur untuk merekap data dari kas masuk dan kas keluar kemudian dijumlah dalam periode 1 tahun. Kas masuk terdiri dari beberapa pembayaran yang telah dilakukan oleh siswa, seperti: Dana kegiatan, UKK, PSG, UAS, UTS dan Dana akhir. Sedangkan data kas keluar terdiri dari: gaji keluar, pembelian ATK, pembayaran wifi, listrik dan telepon. Tampilan dari fitur ini ditunjukkan pada gambar berikut.

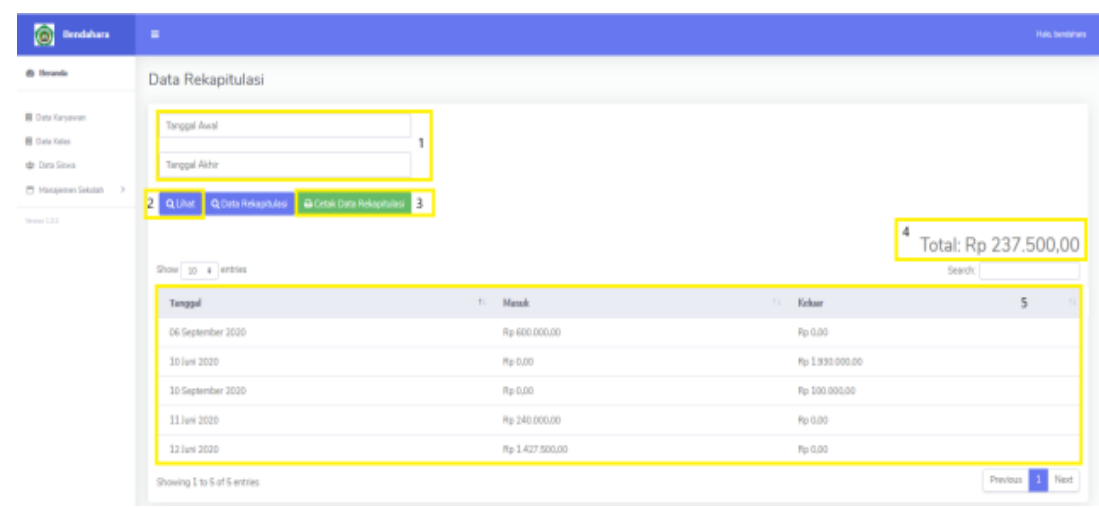

Gambar 16. Menu Data Rekapitulasi

Pada halaman ini juga menyiadakan fitur mencetak transaksi berdasarkan kebutuhan bendahara. Untuk mencetak transaksi ini, bendahara dapat memfilter data data berdasarkan tanggal atau tahun yang diinginkan, sehingga aplikasi akan memproses dan mencetak data hasil fiteran. Hasil cetak dari data rekapitulasi yang telah difilter dapat ditunjukan pada gambar berikut.

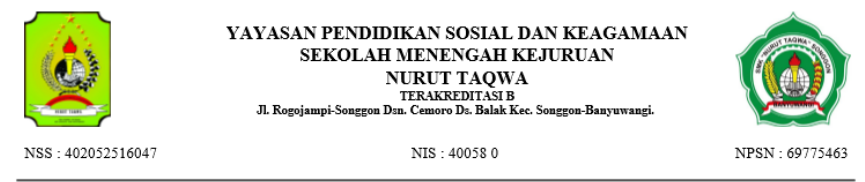

DATA REKAPITULASI TAHUN 2020

\begin{tabular}{|l|l|l|}
\hline \multicolumn{1}{|c|}{ Tanggal } & \multicolumn{1}{|c|}{ Masuk } & \multicolumn{1}{c|}{ Keluar } \\
\hline 10 Oktober 2020 & $\operatorname{Rp~} 1.675 .000,00$ & $\operatorname{Rp~} 0,00$ \\
\hline 09 September 2020 & $\operatorname{Rp~} 300.000,00$ & $\operatorname{Rp~} 0,00$ \\
\hline 12 Agustus 2020 & $\operatorname{Rp~} 0,00$ & $\operatorname{Rp} 2.000 .000,00$ \\
\hline 11 September 2020 & $\operatorname{Rp~} 300.000,00$ & $\operatorname{Rp~} 0,00$ \\
\hline & Total Saldo & $\operatorname{Rp} 275.000,00$ \\
\hline
\end{tabular}

Gambar 17. Hasil Cetakan PDF Data Rekapitulasi

\subsection{Proses WhatsApp Gateway}

Pada proses ini, bendahara harus login terlebih dahulu pada web purindo.net. Jika sudah memiliki akun, setelah masuk klik fitur tanggal yang ada di pojok kanan lalu copy token dan passkey yang terdapat pada web purindo.net agar bisa mengirimkan pesan whatsapp pada wali murid dan karyawan. Bendahara dapat melakukan langkah tersebut apabila ada penggantian token dan passkey. Pesan Whatsapp akan secara otomatis terkirim kepada orang 
tua siswa atau wali murid jika bendahara telah menginputkan data pembayaran siswa dan karyawan yang telah terdaftar pada web aplikasi penerimaan dan pengeluaran kas.

\subsection{Pengujian}

Pengujian sistem merupakan salah satu tahap penting yang dilakukan untuk memeriksa apakah suatu sistem informasi yang dihasilkan dapat berjalan sesuai dengan kebutuhan sistem. Tujuan pengujian sistem adalah untuk menemukan kesalahan atau kekurangan dari sistem yang telah dikembangkan. Pengujian yang dilakukan menggunakan pendekatan blackbox testing dan pengisian kuisioner pada end user. Pengujian ini dilakukan dengan menjalankan sistem informasi dan mengamati hasil pengujian sistem.

Tabel 1. Hasil Pengujian Blackbox

\begin{tabular}{|c|c|c|c|c|}
\hline Kasus Uji & Langkah Penelitian & $\begin{array}{l}\text { Hasil yang } \\
\text { Diharapkan }\end{array}$ & Hasil Pengujian & Status \\
\hline $\begin{array}{l}\text { Pengujian } \\
\text { Beranda } \\
\text { (Bendahara) }\end{array}$ & $\begin{array}{l}\text { Pada halaman beranda } \\
\text { menampilkan profil terkait } \\
\text { dengan grafik kas masuk dan } \\
\text { keluar }\end{array}$ & $\begin{array}{l}\text { Pengguna } \\
\text { (bendahara) melihat } \\
\text { grafik kas masuk } \\
\text { dank as keluar. }\end{array}$ & $\begin{array}{l}\text { Dapat masuk ke } \\
\text { tampilan beranda, dan } \\
\text { menampilkan grafik } \\
\text { kas masuk dan keluar. }\end{array}$ & Sesuai \\
\hline $\begin{array}{l}\text { Pengujian } \\
\text { Tambah Data } \\
\text { Karyawan }\end{array}$ & $\begin{array}{l}\text { Masuk ke menu data karyawan, } \\
\text { pilih sub nemu tambah data } \\
\text { karyawan, klik tombol tambah } \\
\text { mengisi data karyawan } \\
\text { berdasarkan kolom yang tersedia }\end{array}$ & $\begin{array}{l}\text { Menampilkan data } \\
\text { karyawan yang di } \\
\text { tambahkan pada data } \\
\text { karyawan }\end{array}$ & $\begin{array}{l}\text { Dapat menampilkan } \\
\text { data karyawan yang } \\
\text { telah di tambahkan } \\
\text { pada menu tambah } \\
\text { karyawan }\end{array}$ & Sesuai \\
\hline $\begin{array}{l}\text { Pengujian } \\
\text { Tambah Data } \\
\text { Kelas }\end{array}$ & $\begin{array}{l}\text { Masuk ke menu data kelas, pilih } \\
\text { sub menu tambah data kelas, klik } \\
\text { tombol tambah mengisi data } \\
\text { kelas berdasarkan kolom yang } \\
\text { tersedia }\end{array}$ & $\begin{array}{l}\text { Menampilkan data } \\
\text { kelas yang di } \\
\text { tambahkan pada data } \\
\text { kelas }\end{array}$ & $\begin{array}{l}\text { Dapat menampilkan } \\
\text { data kelas yang telah } \\
\text { di tambahkan pada } \\
\text { menu tambahkelas }\end{array}$ & Sesuai \\
\hline $\begin{array}{l}\text { Pengujian } \\
\text { Tambah Data } \\
\text { Siswa }\end{array}$ & $\begin{array}{l}\text { Masuk ke menu data siswa, pilih } \\
\text { sub menu tambah data siswa, } \\
\text { klik tombol tambah mengisi data } \\
\text { siswa berdasarkan kolom yang } \\
\text { tersedia }\end{array}$ & $\begin{array}{l}\text { Menampilkan data } \\
\text { siswa yang di } \\
\text { tambahkan pada data } \\
\text { siswa }\end{array}$ & $\begin{array}{l}\text { Dapat menampilkan } \\
\text { data siswa yang telah } \\
\text { di tambahkan pada } \\
\text { menu tambah siswa }\end{array}$ & Sesuai \\
\hline $\begin{array}{l}\text { Pengujian } \\
\text { Tambah Data } \\
\text { Pembayaran }\end{array}$ & $\begin{array}{l}\text { Masuk ke menu data } \\
\text { pembayaran, pilih sub menu } \\
\text { tambah data pembayaran, klik } \\
\text { tombol tambah mengisi data } \\
\text { pembayaran berdasarkan kolom } \\
\text { yang tersedia }\end{array}$ & $\begin{array}{l}\text { Menampilkan data } \\
\text { pembayaran yang di } \\
\text { tambahkan pada data } \\
\text { pembayaran }\end{array}$ & $\begin{array}{l}\text { Dapat menampilkan } \\
\text { data pembayaran } \\
\text { yang telah di } \\
\text { tambahkan pada menu } \\
\text { tambah pembayaran }\end{array}$ & Sesuai \\
\hline $\begin{array}{l}\text { Pengujian } \\
\text { Tambah Data } \\
\text { Gaji } \\
\text { Karyawan }\end{array}$ & $\begin{array}{l}\text { Masuk ke menu data } \\
\text { pembayaran, pilih sub menu } \\
\text { tambah data gaji karyawan, klik } \\
\text { tombol tambah mengisi data gaji } \\
\text { karyawan berdasarkan kolom } \\
\text { yang tersedia }\end{array}$ & $\begin{array}{l}\text { Menampilkan data } \\
\text { gaji karyawan yang } \\
\text { di tambahkan pada } \\
\text { data gaji karyawan }\end{array}$ & $\begin{array}{l}\text { Dapat menampilkan } \\
\text { data gaji karyawan } \\
\text { yang telah di } \\
\text { tambahkan pada menu } \\
\text { tambah gaji karyawan }\end{array}$ & Sesuai \\
\hline $\begin{array}{l}\text { Pengujian } \\
\text { Chek Data } \\
\text { History } \\
\text { Pembayaran }\end{array}$ & $\begin{array}{l}\text { Masuk ke menu data history } \\
\text { pembayaran, pilih sub nemu } \\
\text { nama siswa dan semester, klik } \\
\text { tombol lihat semua data } \\
\text { berdasarkan kolom yang telah } \\
\text { anda pilih }\end{array}$ & $\begin{array}{l}\text { Menampilkan data } \\
\text { history pembayaran } \\
\text { yang di search pada } \\
\text { data pembayaran }\end{array}$ & $\begin{array}{l}\text { Dapat menampilkan } \\
\text { data pembayaran yang } \\
\text { telah di search pada } \\
\text { data history } \\
\text { pembayaran }\end{array}$ & Sesuai \\
\hline $\begin{array}{l}\text { Pengujian } \\
\text { Chek Data } \\
\text { Kas Masuk }\end{array}$ & $\begin{array}{l}\text { Masuk ke menu data kas masuk, } \\
\text { pilih sub nemu pilih nama siswa } \\
\text { dan tanggal, klik tombol lihat } \\
\text { semua data berdasarkan filter } \\
\text { yang telah anda pilih }\end{array}$ & $\begin{array}{l}\text { Menampilkan data } \\
\text { kas masuk yang di } \\
\text { search pada data kas } \\
\text { masuk }\end{array}$ & $\begin{array}{l}\text { Dapat menampilkan } \\
\text { data pembayaran yang } \\
\text { telah di search pada } \\
\text { data kas masuk }\end{array}$ & Sesuai \\
\hline $\begin{array}{l}\text { Pengujian } \\
\text { Chek Data } \\
\text { Kas Keluar }\end{array}$ & $\begin{array}{l}\text { Masuk ke menu data kas keluar, } \\
\text { pilih sub nemu tanggal, klik } \\
\text { tombol lihat semua data }\end{array}$ & $\begin{array}{l}\text { Menampilkan data } \\
\text { kas keluar yang di } \\
\text { search pada data kas } \\
\text { masuk }\end{array}$ & $\begin{array}{l}\text { Dapat menampilkan } \\
\text { data pengeluaran } \\
\text { yang telah di search } \\
\text { pada data kas keluar }\end{array}$ & Sesuai \\
\hline
\end{tabular}




\begin{tabular}{|c|c|c|c|c|}
\hline & $\begin{array}{l}\text { berdasarkan kolom yang telah } \\
\text { anda pilih }\end{array}$ & & & \\
\hline $\begin{array}{l}\text { Pengujian } \\
\text { Data } \\
\text { Rekapitulasi }\end{array}$ & $\begin{array}{l}\text { Masuk ke menu tampilan data } \\
\text { rekapitulasi, klik cetak } \\
\text { tekapitulasi dan keluar invoce } \\
\text { cetak (PDF) }\end{array}$ & $\begin{array}{l}\text { Menampilkan menu } \\
\text { tampilan } \\
\text { rekapitulasi, dan } \\
\text { cetak invoce (PDF) }\end{array}$ & $\begin{array}{l}\text { Dapat menampilkan } \\
\text { menu tampilan } \\
\text { rekapitulasi, dan cetak } \\
\text { invoce (PDF) }\end{array}$ & Sesuai \\
\hline
\end{tabular}

Tabel di atas merupakan hasil pengujian menggunakan blackbox testing. hasil yang didapatkan dari pendekatan ini didapatkan bahwa semua fitur yang dikembangkan pada penelitian ini "sesuai" atau dapat berjalan dengan baik. Setelah melakukan pengujian blackbox, selanjutnya adalah melakukan pengujian berdasarkan pengisian kuisioner pada pengguna terkait yang berjumlah 10 responden yaitu bendahara, kepala sekolah dan 8 orang karyawan. Pengujian dengan pengisian kuisioner ini berdasarkan 4 aspek 1 menurut ISO 9126 tentang standar terhadap kualitas perangkat lunak yaitu aspek fungsionalitas, informasi, kebergunaan dan efisiensi. Hasil yang didapatkan dari pengujian ini ditunjukkan pada tabel berikut.

Tabel 2. Rekapitulasi Hasil Pengisian Kuisioner

\begin{tabular}{lcccc}
\hline \multicolumn{1}{c}{ Aspek } & $\begin{array}{c}\text { Skor } \\
\text { Aktual }\end{array}$ & Skor Ideal & Prosentase Skor (\%) & Kriteria \\
\hline Fungsionalitas & 136 & 150 & 90.6 & Sangat Baik \\
\hline Informasi & 222 & 250 & 88.8 & Baik \\
\hline Kebergunaan & 177 & 200 & 88.5 & Baik \\
\hline Efisiensi & 218 & 250 & 87.2 & Baik \\
\hline Total & 753 & 850 & 88.5 & Baik \\
\hline
\end{tabular}

Berdasarkan tabel 2 di atas, tingkat kualitas perangkat lunak secara keseluruhan didapatkan skor prosentase rata-rata dari keempat aspek tersebut sebesar 88,5\% yang berarti termasuk dalam kriteria baik. Aspek kualitas tertinggi adalah aspek fungsionalitas dengan prosentase sebesar $90,6 \%$ dan terendah adalah $87,2 \%$ pada aspek efisiensi.

\section{KESIMPULAN DAN SARAN}

Pada penelitian ini dikembangkan sebuah aplikasi penerimaan dan pengeluaran kas di SMK Nurut Taqwa Songgon. Berdasarkan penelitian yang telah dilakukan, didapatkan kesimpulan bahwa 1) Aplikasi ini terdapat dua pengguna yaitu pengguna bendahara dan kepala sekolah. Pengguna bendahara bertugas untuk mengelola data penerimaan dan pengeluaran kas, sedangkan kepala sekolah melihat data penerimaan dan pengeluaran kas, 2) Aplikasi ini membantu wali murid untuk mengetahui informasi pembayaran sekolah yang telah dilakukan putra atau putrinya serta pegawai yang telah menerima gaji melalui fitur WhatsApp Gateway, 3) Aplikasi ini juga dapat memberikan laporan keuangan dalam bentuk pdf untuk keamanan data agar tidak dapat diedit kembali, dan 4) Pengujian sistem dengan menggunakan pendekatan blackbox testing didapatkan bahwa semua fitur yang dikembangkan pada aplikasi ini dapat berjalan dengan baik dan sesuai kaidah perangkat lunak, sedangkan hasil pengujian pengisian kuisioner kepada 10 responden yakni kepada bendahara, kepala sekolah dan 8 orang karyawan menunjukan bahwa tingkat kualitas sistem dalam presentase $88.5 \%$ dengan kriteria baik.

Aplikasi ini dapat dikatakan masih perlu tahap pengembangan lebih lanjut karena masih terdapat kekurangan dari beberapa fitur yang dikembangkan. Beberapa saran yang dapat dipertimbangkan untuk perkembangan lebih lanjut adalah: 1) Tampilan aplikasi ini masih terlihat sederhana, sehingga perlu diberikan sentuhan dengan menambahkan beberapa tampilan yang lebih menarik seperti menambahkan fitur interaksi menggunakan javascript, 2) Aplikasi ini hanya bisa mengirimkan WhatsApp gateway berdasarkan transaksi yang dilakukan oleh siswa saja, diharapkan kedepannya wali murid juga dapat mengetahui tanggungan pembayaran puutra-putrinya melalui fitur WhatsApp Gateway ini..

\section{REFERENCES}

[1] Badan Pusat Statistik, INDEKS PEMBANGUNAN TEKNOLOGI, INFORMASI, DAN KOMUNIKASI/ICT DEVELOPMENT INDEX2018. Jakarta: BPS RI/BPS-Statistics Indonesia, 2019.

[2] N. D. Arizona, Yulia, and R. Saputro, “Aplikasi Pengolahan Data Penerimaan Dan Pengeluaran Kas,” J. PILAR Nusa Mandiri, vol. 14, no. 2, pp. 253-260, 2018.

[3] A. Rochman, A. Sidik, and N. Nazahah, "Perancangan Sistem Informasi Administrasi Pembayaran SPP Siswa Berbasis Web,” J. Sisfotek Glob., vol. 8, no. 1, pp. 51-56, 20218. 
[4] M. Fitriadiansyah and L. Bachtiar, "Sistem Informasi Administrasi Keuangan Pada SMK Negeri 3 Sampit Menggunakan PHP Dan MySQL,” J. Penelit. Dosen FIKOM, vol. 3, no. 1, pp. 1-6, 2015.

[5] Damayanti and M. Y. Hernandez, "Sistem Informasi Akuntansi Penerimaan Dan Pengeluaran Kas pada KPRI Andan Jejama Kabupaten Pesawaran,” J. Tekno Kompak, vol. 12, no. 2, p. 57, 2018.

[6] Lisnawanty and B. Kurniawan, "Sistem Informasi Akuntansi Penerimaan Dan Pengeluaran Kas Berbasis Web (Studi Kasus: Pt. Sinar Kapuas Cemerlang),” J. Ris. Inform., vol. 1, no. 4, pp. 187-196, 2019.

[7] Wablas.com, "Whatsapp and SMS API Gateway Service for Business," 2018. [Online]. Available: https://wablas.com/. [Accessed: 13-Dec-2020].

[8] K. Church and R. De Oliveira, "What's up with WhatsApp? Comparing mobile instant messaging behaviors with traditional SMS," MobileHCI 2013 - Proc. 15th Int. Conf. Human-Computer Interact. with Mob. Devices Serv., pp. 352-361, 2013.

[9] R. S. Pressman, Software Engineering: A Practitioner's Approach, Seventh Edition, 7th Editio., vol. 9781118592. New York: The McGraw-Hill Companies, 2010.

[10] CodeIgniter Foundation, "CodeIgniter 4 Overview," 2020. [Online]. Available: https://codeigniter.com/user_guide/concepts/structure.html. [Accessed: 13-Dec-2020].

[11] J. Z. Gao, H.-S. J. Tsao, and Y. Wu, Testing and Quality Assurance for Component-Based Software. New York: Artech House, 2003.

[12] K. Mohd. Ehmer and K. Farmeena, "A Comparative Study of White Box , Black Box and Grey Box Testing Techniques," Int. J. Adv. Comput. Sci. Appl., vol. 3, no. 6, pp. 12-15, 2012.

[13] R. S. Pressman, Software Quality Engineering: A Practitioner's Approach, vol. 9781118592. New York: McGrawHill, 2010.

[14] P. Berander et al., Software Quality Attributes and Trade-Offs. Blekinge Institute of Technology, 2005. 